\title{
Overview Of Smart City Policy Implementation: A New Approach To Jambi City Government Administration In The Industry 4.0 Era.
}

\author{
Rio Yusri Maulana ${ }^{1}$, Ovie Yanti $^{2}$, Nur Sukmawati ${ }^{3}$ \\ 1,2,3 Universitas Jambi \\ E-mail : rioyusrimaulana@unja.ac.id
}

\begin{abstract}
Industry 4.0 provides technological mastery opportunities as a key to determine of national competitiveness. In line with this, the government needs to build integrated information and communication technology (e-government) services aimed at supporting the realization of the concept. Therefore, the government has legalized a regulation relating to information technology. One of the programs implemented by Ministry of Communication and Information, Ministry of Home Affairs, Ministry of Public Works \& Housing (PUPR), National Development Planning Agency (Bappenas) and the Presidential Staff Office is the Movement Towards 100 Smart Cities which is a joint program of the ministry. The program aims to guide districts / cities in formulating Smart City Master Plans in order to further maximize the use of technology, both in improving community services and accelerating the potential that exists in each region. This study aims to determine the implementation of the Smart City program in the City of Jambi, the innovations that have been implemented, as well as the obstacles and challenges faced in the implementation of the program in the industry 4.0. This study uses a qualitative approach carried out in the city of Jambi. From the results, the implementation of the smart city program began with the Preparation of the Smart City Master Plan of Jambi City in 2014, then the implementation of the development of smart cities that began in 2017 and is still ongoing (2020). To support the implementation of the City of Jambi City smart city program which already has 50 technological innovation applications to support the performance of the Jambi City Government and facilitate the service process to the community. In its application there are various obstacles and challenges such as limited financial resources and limited human resources in the field of information technology, because not all OPD have experts in the IT field.
\end{abstract}

Keyword: Smart City, Industrial Revolutions 4.0, Public Policy.

\section{INTRODUCTION}

The rapid development of today's development, should be faced by preparing various strategies to deal with it, especially in the era of the 4.0 industrial revolution characterized by increased connectivity, interaction, and modernization of technology and information that is able to change various aspects in human life. The 4.0 industry revolution gives the opportunity to mastery technology as the key to determining national competitiveness. Therefore, mastering technologies such as the internet of thing, artifificial intelligence, human-machine interfaces, robotic and sensory technology, and 3D technology will sustain development in the era of the 4.0 industrial revolution.
In accordance with the era of the 4.0 Industrial Revolution, the government needs to build an integrated information and communication technology based service $(e$ government). With the integrated system of the community will feel the impact and benefits of the advancement of Information technology and communication where the service becomes easy, fast, inexpensive, and quality such as facilities in the management of correspondence and licensing, ease in public complaints, transparency in public services, adequate transfortation means, and so forth.

The form of the program implemented by the Government through the Ministry of Communication and Informatics, Ministry of Interior, Ministry of PUPR, Bappenas and presidential staff 
office is the movement to 100 Smart City (hereinafter abbreviated to SC) which is a joint program of the Ministry. This Program aims to invite $\mathrm{Kab} / \mathrm{Kota}$ can to plan the Master Plan SC in order to further improve the use of technology, both in improving service to the community and accommodating the potential contained in each region (www.kominfo.go.id).

Smart City is an application of the internet of things (IoT). The role of the Internet to realize the concept of SC is so important to support the delivery of information and perform the action through the network with minimal human intervention, so as to perform various functions automatically. With the Internet of thing in the SC program will unite the community in a fast and precise service.

To overcome the problems faced by the community. Through the concept of smart city, make the government's auth can be more instant, and give impact to the community. The first step, smart city construction was prioritized in 24 cities with a benchmark of budget availability. The district/city is as follows:

Table 1. District/City Movement Program 100 Smart City in Indonesia

\begin{tabular}{|c|l|c|l|}
\hline No & \multicolumn{1}{|c|}{ District } & No & \multicolumn{1}{|c|}{ City } \\
\hline 1 & Banyuwangi & 1 & Tomohon \\
\hline 2 & $\begin{array}{l}\text { Lombok } \\
\text { Timur }\end{array}$ & 2 & Sukabumi \\
\hline 3 & Badung & 3 & Samarinda \\
\hline 4 & Sleman & 4 & Bandung \\
\hline 5 & Banyuasin & 5 & Semarang \\
\hline 6 & Bojonegoro & 6 & Tangerang \\
\hline 7 & Gresik & 7 & Bekasi \\
\hline 8 & Sidoarjo & 8 & Bogor \\
\hline 9 & Mimika & 9 & Cirebon \\
\hline 10 & Kutai & 10 & Pelalawan \\
\hline 11 & Siak & 11 & Makasar \\
\hline & & 12 & $\begin{array}{l}\text { Tangerang } \\
\text { Selatan }\end{array}$ \\
\hline & & 13 & Jambi \\
\hline
\end{tabular}

*Source : www.kominfo.go.id
Jambi City is one of the cities that continues to develop the smart City program in every aspect of community life. The basic concept of development is efficiency in budgeting to provide effective public services, making it easier for people to obtain services using information technology. However, in its application each city has different problems including the city of Jambi, such as inadequate supporting infrastructure, the readiness of local government, one of them in terms of budget, and the community that stutters technology.

Smart City in Jambi has started since 2014 then. In the implementation, there are still constraints such as human resources limitation because not all regional device organizations have experts in the IT field. Another obstacle is the city of Jambi faced with considerable challenges such as a high population increase, less reliable transportation, as well as infrastructure that has not supported, the quality of public service that has not been in accordance with the expectations of society and the number of practice Pungli, and most importantly the challenge to the limited financial resources become a problem in order to realize the program Smart City (Smart City) in City Jambi. Based on the phenomenon that has been outlined, researchers are interested to study in more depth about this smart city program in a study titled "Review of Smart City Program implementation" in Jambi city in the Era of Industrial Revolution 4.0.

\section{RESEARCH METHODS}

The study uses a descriptive method with a qualitative approach. With this method the researcher seeks to describe the implementation of Smart City program in Jambi City in the revolution of the 4.0 industry by sampling as a research informant is the institution and apparatus involved in the implementation of the smart city program, namely the Office of Communication and Informatics City of Jambi which is located at Jln. Jend. Basuki Rahmat No. 1 Kota Baru Jambi - Indonesia 36128. Data is collected through observation 
activities, interviews and documentation. Then the data is analyzed with interactive models which include data reduction, data presentation, and withdrawal of conclusions.

\section{RESULTS AND DISCUSSION \\ 1. Implementation of Smart City Program in Jambi City.}

Jambi City has focused as a smart city, this program is beginning with the preparation of Master Plan Smart City of Jambi City in 2014, together with the element OPD, subdistrict government, government village, head of health centers in the area of Jambi city, as well as board Smart City of Jambi City consisting of all head OPD City Jambi, elements DPRD Jambi city and academics. After the technical guidance of the preparation of Master Plan Smart City Jambi City, the next stage is the implementation of smart city development which began in 2017 and still ongoing until now (2020) under the guidance and mentoring of the Indonesian IT Consultant Association (IKTII).

Service to the community began to be enforced with an IT system connected with all the OPD of Jambi city government. In order to improve the implementation of Smart city, Jambi city government has always coordinated with the head of SKPD to expose problems in the respective institutions that can be solved through technology so as to facilitate in serving the community.

In building and implementing Smart City, Jambi City is the first area in Sumatera has a City Operation Centre that is named Jambi City Operation Centre (JCOC). It is a space control of Jambi city which monitors the activities occurring in the City of Jambi, including having the function of monitoring the traffic by implementing the application of the Traffic Control System (ATCS). In addition to displaying the city information, JCOC also monitors public complaints through the SIUPSET app. To support the implementation of JCOC, almost every intersection in Jambi City already installed CCTV. In addition, from the implementation of the Smart city of Jambi City, is with the electronic traffic Law Enform (E-TLE) or called electronic ticketed. Jambi City is the second region to implement E-TLE in Indonesia after DKI Jakarta.

As proof of the success of the Jambi city government in implementing the Smart City program, the city government of Jambi gained appreciation from the central Government through the Ministry of Information and Communication as one of the 25 pilot areas (pilot project) of Smart City in Indonesia. In addition, the city government of Jambi also gained appreciation from one of the leading national magazines engaged in the IT and telecommunications field, IT Works, which initiated the Event TOP IT \& TELCO 2018. The city of Jambi has been able to collect two awards, namely Top Leader on IT Leadership 2018 and Top IT Improvement 2018. In the year 2019, the city of Jambi also managed to get 3 awards at the Expo Smart City 2019 exhibition at Balai Sudirman Jakarta. The form of the award is capability Award and Implementation of Smart city governance in the form of Top Digital Implementation 2019 on City Government Level Star 4, Top Digital Transformation Readiness 2019, and Top Leader on Digital Implementation 2019.

That currently the city of Jambi has indeed transformed as a city that implements the concept of smart city well. Various government activities and public services have been implemented in the form of information technology-based service applications. The concept of smart city of Jambi City is also not separated from the industry 4.0 phase, which demands the utilization of information and communication technology in all aspects of community life, so it can provide benefits and facilitate all public activities.

2. New findings that have been applied in order to support the Smart City Program in the city of Jambi D Era Industrial Revolution 4.0. 
To support the implementation of Smart City program in Jambi City, the city government has launched and has approximately 50 technology innovation applications to support the performance of the Government of Jambi and facilitate the process of service to the community. All these technological innovations can be accessed easily by the community.

The applications include E-TLE, Si upset (Online community complaints Information System), DISHUB Sign On, DISHUB Smart, Si Raja Koja (Information System procurement goods provision of Jambi city), licensing applications, United Nations Info Online, Applications Jambi City (information about the city of Jambi), digitalization archives, Digital clipping applications, and applications PPID (Public Information application). With the various applications of the community services, The Jambi City Government hopes that government services to the public can run effectively and optimally, and can respond to the challenges of the contemporary community to the needs of the service system is fast, integrated, inexpensive and efficient.

Even to support Smart city in Jambi City, Jambi city government has built Fiber Optic (Fo) to facilitate and expand the coverage of telecommunication network. Based on smart city dimensions/indicators, as examples of such applications include :

Table 2. Smart City Applications

\begin{tabular}{|c|c|c|}
\hline No & Smart City Variables & Applications \\
\hline 1 & Smart Economy & $\begin{array}{l}\text { Sikadd } \\
\text { E-Promosi }\end{array}$ \\
\hline 2 & Smart People & \begin{tabular}{|l|} 
Sangkek \\
Aplikasi PPID
\end{tabular} \\
\hline 3 & Smart Government & \begin{tabular}{|l|} 
Sikoja \\
Sikesal \\
Sipaten \\
Sipadek \\
Si Raja Koja \\
\end{tabular} \\
\hline 4 & Smart Environment & Sippolling \\
\hline 5 & Smart Mobility & \begin{tabular}{|l} 
Transkoja \\
E-Parking \\
E-TLE \\
Dishub Sign On \\
Dishub Smart \\
\end{tabular} \\
\hline 6 & Smart Living & \begin{tabular}{|l|} 
E-Silola \\
E-Planning \\
Aplikasi Perizinan
\end{tabular} \\
\hline
\end{tabular}

\section{Barriers and challenges faced in the implementation of Smart City Program in Jambi City}

As one of Smart City, Kota Jambi performs various innovations by building integrated services based on applications in various fields, but in its application there are various obstacles and challenges. The barriers are limited financial resources, therefore one solution is to seek the participation of stakeholders in creating a smart city in Jambi. Other obstacles and challenges are the limitation of human resources in the field of information technology, because not all OPD have experts in IT field.

This was supported by interviews with the head of Jambi City Communication and Information Department, Mr. Nirwan that :

Jambi City has focused itself into a smart city. Service to the community is enforced using IT that is connected with all the OPD of Jambi city government. This is to facilitate service and minimize face-to-front between the officers and the community. However, there are constraints in its implementation, which is the limitation of human resources, because not all OPD have experts in IT field. To overcome that problem, we continue to provide mentoring.

Other obstacles and challenges are the lack of readiness of the community in utilizing such application-based technologies. Even there are still people who do not know to facilitate the service and absorb the aspirations of the government of Jambi City has a variety of supporting applications. As the result of the interview with Nirwan :

Jambi city government already has dozens of applications, among them there are applications for the development planning of Jambi City, service 
applications, application of complaints and information.

The opinion as researchers have outlined above. Therefore, Jambi city government is very concerned with the response given by the public to application of such technological innovations as a form of feedback for the government in conducting a improvement to the Smart City Program.

\section{CONCLUSION}

The implementation of Smart City Program in Jambi City has started since the year 2014 is in the order of Master Plan Smart City Jambi City. The implementation of Smart city development began in 2017 and is still ongoing until now (2020) under the guidance and mentoring of the Indonesia IT Consultant Association (IKTII). As proof of the success of the Jambi city government in implementing the Smart City program, the city of Jambi won the

Implementation of Smart city governance at Expo Smart City 2019 exhibition at Balai Sudirman Jakarta.

In support of the Smart City Program in the city of Jambi D Era Industrial Revolution 4.0. The Jambi city government has launched and has approximately 50 technology innovation applications to facilitate the process of service to the community. All these technological innovations can be accessed easily by the community. However, there are several challenges faced in implementing the Smart City Program in Jambi City is a limited financial resources, limitation of HUMAN resources in information technology, and lack of public readiness to utilize application-based technology.

\section{BIBLIOGRAPHY}

Abdurrozzaq Hasibuan \& Oris Krianto Sulaiman. Smart City Concept Smart City as Alternative Urban Problem Solving Regency/City in Major Cities Of North Sumatra province. Principal Bulletin of
Engineering, Volume 14 number 2, January (2019:127).

Article. id.techinasia.com. In Access January 3, 2020.

Budi Sutrisno \& Idil Akbar. E-Participation in local development (Smart City Implementation study in Bandung City). Socioteknologi Journal, Volume 17 number 2, February (2018:191).

Chandra Eko Wahyudi Utomo \& Mochamad Hariadi. Smart City Development Strategy for the city community. Strategy and business journals, Volume 4 number, October (2016:159).

Danang Setiadji. What is Smart City and its application challenges in Indonesia.

Harbani Pasolong, 2012, Research Method Of Public Administration, Bandung, Alfabeta.

Law number 11 of 2008 on electronic information and transactions. Regulation of the Ministe

Lexy J. Moleong, 2011, Qualitative Research Methodology, Bandung, Rosdakarya youth.

Listhari Baenanda. Know more about the Industrial Revolution 4.0. Article. University of Waikato. binus.ac.id. In Access January 3, 2020.

Mardalis, 2010, Research method A Proposal Approach, Jakarta, Earth Aksara.

of administrative reform and bureaucratic reforms (Menpan RB) No. 06 Year 2011 on Electronic service manuscript.

Overview Implementasi Smart City Di Kota Jambi di tengah Paradigma Industry 4.0.

Presidential Regulation No. 95 Year 2018 on electronic-based government system (SPBE).

Sugiyono, 2012, Research Method Of Administration, Bandung, Alfabeta.

Supli Effendi Rahim, DKK, 2013, Sundries Of Electronic Government (E- 
Jurnal Ilmu Sosial dan Pendidikan

http://ejournal.mandalanursa.org/index.php/JISIP/index

Terakreditasi Peringkat 5 (No. SK: 85/M/KPT/2020)

Government), Palembang, UNSRI Press.

Triayudi, et al. Computer network

\footnotetext{
infrastructure Design in the concept of building an attack to Smart City. Prosisko Volume 1. September. 2014.
}

Vol. 4. No. 4 November 2020

p-ISSN: 2598-9944 e- ISSN: 2656-6753 